\title{
MEDICAL SCIENCE IN INDIA
}

$\mathrm{P}^{\mathrm{r}}$ ROF. V. R. KHANOLKAR, National professor of medicino, Bombay, has presented an admirable review of the progress of medical science in India*. The art of modicine in India was inculcated in novitiates in the very oarly Vedic period (probably c. 1500 B.c.). The healing art was closely associated with religious practices, and medical knowledge remained mainly the prerogative of the priests and scholars. Two main centres of medical teaching were established at Taxila and Varanasi (Benares). After the conquests of Alexander (327 B.c.), the Greeks borrowed many ideas from Hindu physicians and surgeons and incorporated them in Greek medicine. With the Muslim conquest of India the teachings of Avicenna and Rhazos wero introduced and widely practised by Hakims as the basis of the Tibbi and Unani systems of medicine.

Following the entry of Europeans in India, Western medicine was introduced and gained favour with the general public. It gradually took precedence ovor other systems of medicine and, in 1822, the first medical school was establishod for the teaching of medicine. In 1833, ic committee, appointed to examine medical education in India, recommended the establishment of medical colleges instead of medical schools, and the first medical colleges were sot up in Calcutta and Madras in 1835. Ten years later, a third medical collogo was opened in Bombay. In 1916 the first medical college for womon only was establishod in Delhi.

In 1857 the Universities of Bombay, Madras and Calcutta wore affiliated to theso Colleges. As they were found unequal to supply the necessary trained doctors for the country, twenty-eight medical schools with short courses had to be started. By 1926 there wore ten medical colleges in British India and two in Indian States. Following independence, there was a sharp rise in the number of medical colleges and thirteon now colleges wero establishod during 1946-49 and twenty-one moro in the period 1950 . 58 , so that by 1959 the total number of medical colleges was fifty. Those colleges include teaching institutions under the Central and State Governments, universities, municipal corporations and private and missionary organizations. At present, these colleges provide for 5,000 admissions annually, and it is expected that, with the establishment of fifteen new colleges which may be sot up by the ond of the third Five Year Plan, the admissions to the modical course of studies will increase to 6,500 . Medical scienco has progressed rapidly in India during tho past fifty years. It has kept pace with dovelopments in this field of scienco in Europe and North America. The problems which have engaged the attention of the medical men have been many and varied in nature. Work has been directed towards the fundamontal nature of disease processes, as well as the causation, pathogenesis and treatment of particular morbid conditions.

Prof. Khanolkar gives an admirable account of the work undertaken by various research workers under the headings: communicable disease; respiratory diseaso other than tuberculosis; cardio-vascular diseases; hæmatology ; ondocrinology; nutritional research; environmontal hygione and sanitation; industrial health; maternal and child hoalth; dontal hoalth; nourology; mental health; cancor; ophthalmology; orthopadic studies; and drug research.

\section{Tropical Medicine}

The most significant feature in the field work undertaken by the Calcutta School of Tropical Medicine and

* Indian Science Congress Association. Fifty Years of Science in India. Progress of Medical Science. By V. R. Khanolkar. Pp. 50. (Calcutta-17: Indian Science Congress Association, 1963.) Rs. 1.50 . the Carmichael Hospital for Tropical Diseases during 1961-62 was the measure taken to combat an outbreak of lathyrism. This has been described by the director. Dr. R. M. Chaudhuri, in the annual report $\dagger$, whore he attributes the outbreak to consumption of Khesari. widely cultivated locally with soods brought from Bihar, the known endomic area. Morphologically, they were of much larger size than the Bengal variety. Tho villages had resorted to Khesari cultivation as the heavy flood in 1955 made most of the arable land unsuitable for rice crops. The pulse (de-husked) was consumed liberally for 3-5 months a yoar. Many patients wero oxamined in the field and somo wore brought and admitted to hospital for detailed examination. Tho history revealed that symptoms usually appeared after two months of Khesari consumption. Many sharing the same diet were, however, unaffected.

Clinical and laboratory data indicated the disease to bes of the nature of antigon-antibody reaction with prodilec. tion of the spinal cord in the dorsolumbar rogion. which has a relatively poor vaseularity - the system being sensit izod to an oxtent depending on the individual sensitivity. In treatment, prostigmin was found to be of distinct value. Instruction for propaganda against lathyrus cultivation and consumption met with suecoss in the prevention of the disease in the aroa. Compared with 29 fresh cases in 1959, there wore 6 and 5 new cases encountered in 1960 and 1961 respectively. In the Bandipur Union of the Hooghly district, a parasitological survey is being made to ascertain the prevalenco of infections in the rural area and the morbidity attributable to them. The survey is to cover 10 per cent of the total population $(14,000)$ of the area, worked out on a family basis-the average family size being 6.7 .

Observations already indicate a high prevalence of hookworm infection (about 75 per cont), while that of other important parasitic infections, for example, ascaria. sis, filariasis, amobiasis, seoms to be less than 5 por cent. A clear reflexion of environmontal sanitation, food habits. socio-economic condition, and oceupational and other practices on the disease distribution is shown. Despite the high prevalence of hookworm infection, the worm load. is not high. The explanation of this is likely to come through a closer study of the prevailing epidt miological set-up or the immunological status of the population.

The report also includes accounts of various departmontal research activities.

\section{Virus Research}

The Virus Research Centre, Poona, which is jointly maintainod by the Rockefeller Foundation and the Indian Council of Medical Research, completed its first docade of existence in the beginning of 1962 . It is now located in a fully equipped laboratory of its own in Poona City with two field stations: one at Sagar in Shimoga District of Mysore State and the other in the Departmont of Microbiology, Christian Medical College and Hospital, Vollore, in Madras State. A small fiold unit was also maintainod at Shimoga for studying experimental viræmia in the local species of birds. In 1962 the staff consisted of nineteen profossional workers and throe assistants, in addition to laboratory, field and administrative assistants and helpors.

Though primarily devoted to rosenrch on the epiderniology of arthropod-borne viruses occurring in India, as a part of the Rockefeller Foundation's global intorest in the

+ Annual Report of the Calcutta School of Tropical Medicine and the Carmichael Hospital for Tropical Diseases, 1961-62. Pp. $1+150+2$ plates pital for Tropical Medicine, 1963.) 
subject, the Virus Research Centre has served as a centre for research and training in virology and has given facilities to many workers, both Indian and foreign, for acquiring practical knowledgo in the techniques of virology.

During the decade of its existonce, the Virus Research Centre has carried out a large number of investigations, among them being: (1) serological surveys for arboviruses in several parts of India; (2) 'Jamshedpur fever' and a similar disease (the so-called 'mystery disease') prevailing in several cities of North India in the year 1953-54 and subsequent outbreaks of encephalitis in Nagpur, Delhi and other places; (3) Japanese encophalitis and its related problems in Madras, Andhra, Pradesh and Mysore States; (4) Kyasanur Forest disease, a new tick-borne virus disease of man and monkeys in the forests of Mysore State, and its possible occurrence in other parts of India; (5) the epidemiology of dengue fever in Madras State and the recognition of the occurrence of dengue type 4 in
India; (6) the outbreak of African horse sickness for the first time in the Indian sub-continent in the year 1960; (7) the outbreak of infectious hepatitis in Dolhi; (8) laboratory and field studies on mosquitoes, particularly in Poona district and in South India; $(9)$ tho taxonomy and bohaviour of Indian species of ticks; and (10) the avian and mammalian fauna of India and their potentialities as disseminators of virus diseases.

The Centre has undertaken several invostigations on viruses other than arboviruses, such as rabies, Newcast le disease (Ranikhet), herpes, Coxsackie and other entero. viruses. The impetus given to medical zoology including medical entomology has been significant. Full details of the work of the Centre are described in its annual report for $1962 \ddagger$. \pm Indian Council of Medical Research, New Delhi. 1962 Annual Report.
of the Virus Research Centre, Poona. Pp. iv $+114+1$ plate. (New Delhi: Indian Council of Medical Researeh, 1963.)

\section{TOXIC CHEMICALS IN AGRICULTURE AND FOOD STORAGE}

$\mathrm{T}$

HE report of the Research Committee on Toxic Chemicals*, which was set up at the request of the Minister for Science by the Agricultural Research Council, under the chairmanship of Prof. A. C. Frazer, does not point to any major gaps in research on pest-control products at the present time, but recommends that certain aspects of research should be strengthened. The report is a sequel to the report in September 1961 of a Research Study Group on Toxic Chemicals used in Agriculture and Food Storage, of which Dr. (now Sir Harold) Sanders was chairman. The Committee was to review research carried out under the auspices of the four Research Councils on the effects of toxic chemicals used in agriculture and food storage and to make recom. mendations for future research. It appointed working parties to consider particular aspects such as ecological studies, plant breeding, biological control and other alternative methods which might reduce risks to wild animals and plants. These subjects are discussed in the first sections of the report, following which the main research problems are considered under eight headings: the assessment of hazards arising from the use of pestcontrol products; development of methods of pest control; development of new products; control of potential hazards; co-ordination of effort; man-power; further research needs; and priorities.

Work is already proceeding on all the problems discussed, and a useful feature of the report is the appended summary of work in progress. Further work, however, is urgently needed on the behaviour and accumulation of pest-control products in soil and water and their effects on soil organisms and on aquatic flora and fauna, as well as on the possibility of breeding for resistance to important insect pests in crops where no satisfactory control is known, or where the present chemical methods are unsatisfactory. Further ecological investigations on whole populations of pests and other species are required to provide essential background information, and here it is suggested university departments of botany and zoology might contribute. It is also doubtful whether research into the exploitation of diseases of insects as a method of control is adequate. The Committee suggests that there is a case for establishing an insect pathology laboratory, concentrating in the first place on bacterial and virus diseases of insects. Support of the fundamental work required for the more effective use of sterilants, attractants and repellants for control purposes is urged, as well as toxicological investigations to relate the levels of pesti-

- Agricultural Research Council. Report of the Research Committee on Toxic Chemicals. Pp. iv +38 . (London: Agricultural Research Council A vailable from H.M. 0,1964 .) 28 . $6 d$. cides found in tissues of birds and mammals and possible toxic effects. This would supploment the information from ecological examinations, but continued support is required for investigations on the biochemistry and toxicology of pest-control products. This is fundamental to the interpretation of data obtained by analytical surveys, the discovery of new products to control resistance, or the development of safer, more selective and less-resistant products, as well as to the discovery of diagnostic tests of exposure to or poisoning by such products, and the successful treatment of those who may be poisoned. Attention should also be directed to the development of quantitative methods of analysis suitable for use by public analysts and others, and here a central source of information is needed. Further effort is required on work that may lead to the development of safer, more selective and less persistent products, while if it is decided to establish a monitoring service as part of the control organization those concerned with research should be kept fully informed of the results.

Most of these recommendations are directed specifically to the attention of the Agricultural Research Council. The Committee also recommends that the attention of the Medical Research Council should be directed to the need for: (1) evaluating the toxicological significance of the presence of these products in human tissues; (2) continuing support and development of toxicological and biochemical investigations on pest-control products in mammals; (3) ensuring that every suspected case of such poisoning in man is fully investigated and the information obtained made known to the Research Committee. The Department of Scientific and Industrial Research should note the need for establishing a central source of information on the chemistry and analysis of these products and their residues (for which purpose the Laboratory of the Government Chemist is suggested as being appropriate) and for research investigations on the development of analytical methods necessary and suitable for a monitoring system if this is considered desirable. The Nature Conservancy should consider the need for further ecological investigations on whole populations of chosen species, and for examining the practicability of controlling a land area of 1,000 acres in such a way as to permit quantitative investigations of the effects of pest. control products on wild-bird population. Moreover, co-operation is required, for example, with river boards and Government departments concerned with water resources, in examining contamination of fresh water by chemical products, in studying the accumulation of such products in animals, and in studying the faunal and floral changes in inland waters. 